\title{
Stock Prices Analysis of State-Owned Enterprise and Non-State-Owned Enterprise in Response to Negative Information Period 2017-2019
}

\author{
Raka Daniel Lihardo Sumbayak ${ }^{1}$, Tony $\operatorname{Irawan}^{1} \&$ Trias Andati $^{1}$ \\ ${ }^{1}$ School of Business, Institut Pertanian Bogor, Bogor, Indonesia \\ Correspondence: Raka Sumbayak, School of Business, Institut Pertanian Bogor, Bogor, Indonesia. E-mail: \\ danielraka1994@gmail.com
}

Received: February 18, 2020

Accepted: March 15, 2020

Online Published: May 30, 2020

doi:10.5539/ijbm.v15n6p204

URL: https://doi.org/10.5539/ijbm.v15n6p204

\begin{abstract}
There were bad news affected stock prices, i.e. Fraud and bad financial performance. Fraud on State Owned Enterprises (SOE) listed companies was suspected to have a stronger impact on stock prices compared to Non-SOE issuers. The effect of bad financial performance on Non-SOE issuers was thought to have a stronger impact on stock prices when compared to SOE issuers. This research was conducted on SOE and non-SOE that experienced fraud and bad financial performance from 2017 to 2019. Data analysis was performed with the Google Search Volume Index, Difference Test, and Multiple Linear Regression Analysis. The data from Google Search Volume Index showed that SOE issuers were more searched by the public when compared to Non-SOE issuers in responding to Fraud and bad financial performance. Linear Regression Analysis found that the decline in stock prices of SOE issuers was lower than the Non-SOE issuers in response to Fraud. The decline in stock prices of SOE issuers in response to the bad financial performance in the Property and Finance sectors was lower than the decline in stock prices of Non-SOE issuers. However, the decline in the stock prices of Non-SOE companies in response to the bad financial performance in the Basic Industry sector was lower than the SOE issuers. This could be influenced by SOE stock ownership dominated by the Indonesian government and the existence of a Conservatism Bias.
\end{abstract}

Keywords: bad financial performance, fraud, SOE, Non-SOE

\section{Introduction}

Beers (2019) stated that there was some negative information that could negatively inluence stock prices of company. One of those information were bad performance of financial sector, bad management of company, and disaster had by the company. In addition, Cuellar et al., (2009) asserted that information such as Fraud, selling assets, bad perception of consumers on company's product and service could influence negatively stock prices. From those negative information, Fraud and bad financial performance were frequently occured in 2017 to 2019. There were some Fraud on listed companies in BEI in the last 3 years, for example LPCK, LPKR, AISA, WSKT, KRAS who performed Corruption Fraud and GIAA who performed Financial Statement Fraud. The Financial Services Authority (OJK) report that there are 48 companies with bad performance of financial sector per 13 of August 2019.

There was a perception on investor that SOE gave stock performance better than Non-SOE. It was seen in the average of daily return of SOE compared to its sectoral index, for example in the average of daily return for January $1^{\text {st }} 2019$ to September $9^{\text {th }} 2019$. Average of daily return which each of SMGR and WTON in sectors of basic and chemist industries were higher at $0,07 \%$ and $0,14 \%$ than its sectoral index. It was also seen in TLKM and JSMR which gave average of daily return at each $0,1 \%$ and $0.08 \%$ which was higher than its sectoral index. ELSA, ANTM, and TINS which were from mining sector also showed average of positive daily return, even the sectoral index showed negative (Yahoofinance, 2019). Moreover, investor has an opinion that investment in SOE is safer than in Non-SOE. It was related to the government who took part in every activity done by SOE. Furthermore, if SOE had a financial problem, the government could increase capital investments to SOE.

There was a difference caused by effect of Fraud between SOE and Non-SOE, for example Fraud were detected in SOE company such as GIAA (PT Garuda Indonesia) and Non-SOE LPKR (Lippo Karawaci). PT Garuda 
Indonesia was alleged for fraud in financial report. Garuda Indonesia listed receivables that had not been accepted by the company. Negative Information decreased stock price of GIAA into 38 points on the first day after the occurence (Yahoofinance, 2019). The example of Fraud's effect on Non-SOE company was on LPKR. One of directors Lippo group was entangled in corruption. Negative information decreased stock price of LPKR to 13 points on the first day after the occurence (Yahoofinance, 2019). There were also a different impact of bad financial performance between SOE and Non-SOE. Bad financial performance was proxied with ROA value of company which was under sectoral ROA value. As an example in BBTN as SOE company and BNGA as Non-SOE company in financial sector. ROA of BBTN in 2018 was 1.09 and it was under sectoral ROA with 1.15. After financial report of BBTN 2018 was released, stock price of BBTN increased 20 points on the second day after the occurrence. BNGA ROA in 2018 was 0.42 and it was under sectoral ROA which was 1.15 . The information decreased stock price of BNGA to 50 points on the second day after the occurence (Yahoofinance, 2019).

There was a difference between SOE company and Non-BUMN company in responding negative information. In investment activity, investor would certainly faced negative information on the company selected when making a decision. There was a difference of stock price trend between SOE and Non-SOE after the existence of negative information, that had implication in selecting a company to invest by investor. In addition, Fraud and bad financial performance have different impact on stock price. It showed that it need an analysis to compare Fraud to bad impact in SOE and Non-SOE. It indicated that it needed to analyze stock price trend between stock price of SOE company and stock price of Non-SOE company in response to negative information. This study aimed to compare Fraud and bad financial performance between SOE and Non-SOE and compare between Fraud and bad financial performance in each SOE and Non-SOE.

\section{Literature Review}

Cox \& Weirich (2002), and Feroz et al., (1991) stated that stock market reacted negatively to Financial Statement Fraud. Tay et al., (2016) showed that Corruption Fraud affected negatively towards stock price and decreased abnormal return on the average at $3,16 \%$ on the first month and $1,92 \%$ on the second month after announcement. On the other hand, Rao (1997) asserted that Fraud did not affect stock price. It was related by the inefficiency of stock market in response to Fraud information. Ang \& Ding (2006) conducted a study on the comparison of performance of Singapore's SOE and Non-SOE in Singapore's stock market. The study showed that SOE in Singapore had better performance than Non-SOE. It was related to profitability, solvability, and size which was bigger for GLC compared to Non-GLC. Soejono (2010) also showed that SOE gave better stock performance rather than Non-SOE. It was related by shares ownership of SOE company which was dominated by government. In contrast, Razak et al., (2011) claimed that Non-GLC gave better performance than GLC.

Hypothesis of this study were decrease of stock price of SOE company is higher than Non-SOE company in response to Fraud. The decrease of stock price of SOE company was lower than Non-SOE company in response to bad financial performance. A decrease of stock price of SOE company in response to Fraud were higher than the response of SOE company to bad financial performance. A decrease of stock price of Non-SOE company in response to Fraud were higher than response of Non-SOE company to the bad financial performance.

\section{Method}

Data collection was done by taking the data of stock price of companies of KRAS, GIAA, WSKT, LPCK, LPKR, AISA for Fraud information and companies of SMCB, PTPP, BBTN, IMPC, CTRA, and BNGA for information of bad financial performance. Information of Fraud and bad financial performance taken were information in 2017 to 2019. Negative information of Fraud was proxied with information of Financial Statement Fraud and Corruption Fraud. Information of bad financial performance were proxied with company ROA which under the average of ROA of its sector, it was also adjusted to the value of its market capitalization. The data taken was a closing data of daily stock price with time span of negative information on each company and data of IHSG. Data analysis were done by using Searching Volume Index (SVI) to see how often the sample of company in the study were viewed or analyzed by investor. In addition, it also conducted normality test, multicollinearity, autocorrelation, and heteroscedasticity for classical assumption test. Then, Difference Test of Paired Sample $\mathrm{t}$-Test was done in every company which was detected to negative information to see whether the negative information affected those companies. In addition, analysis of linear regression was also done to compare the impact of Fraud and bad financial performance between SOE and Non-SOE with an addition of market variable (IHSG).

\subsection{Google Search Volume Index (GSVI)}

Rui (2015) stated that Google Search Volume Index was a tool analysis developed by google to see how often the 
search specific key was relatively sought against the entire search in internet, by the period that was decided by the user, GSVI. GSVI analysis to see how often information of each sample of company was sought by public or investor. The calculation of GSVI was done by calculating daily Search Interest as follow:

$$
\text { Search Interest }=\frac{\# \text { queries for specific keyword }}{\text { Total Google Search queries }}
$$

Where:

\#queries for specific keyword: number of search on pertinent company

Total Google Search queries : Total of the entire search

Every Search interest on each day was divided by the highest Search Interest in the decided period, and it was indexed in the scale of 0-100, thus it obtained value of GSVI (Rui, 2015). GSVI in this study was done to see how often Fraud information and bad financial performance were sought by public. Analysis of Fraud used weekly data with the time span from the day of the case of Fraud to a year after the case. Analysis of bad financial performance used daily data with the time span from financial report in 2018 release day until the release of financial report on the first quarter of 2019 on each sample of bad financial performance.

\subsection{Difference Test of Paired Sample t-Test}

Difference test was done to evaluate certain treatment in one similar sample in two different periods of observation (Widiyanto, 2013). In this study announcement of negative information was a treatment and the period is $\mathrm{t}-7$ before and $\mathrm{t}+7$ after the announcement of negative information. According to Widiyanto (2013), Paired Sample t-Test was one of testing methods used to review effectiveness of treatment, indicated by the difference of average before and after giving treatment. Difference test was done on each company which was selected as sample. Widiyanto (2013) state that the formula of Paired Sample t-Test is as follows:

$$
\text { thitung }=\frac{\bar{D}}{\frac{S D}{\sqrt{N}}}
$$

Where:

$\bar{D}$ : Difference of stock price average before and after announcement of negative information

$S D$ : Standard deviation of stock price difference before and after announcement of negative information

$\mathrm{N}$ : number of samples

\subsection{Analysis of Multiple Linear Regressions}

Analysis of multiple linear regressions was done to see how Fraud and bad financial performance affected stock price of SOE company and Non-SOE company. The time span that used in analysis of regression was one month before the case and one month after the case. Linear regression was done on each sample of company. IHSG as an independent variable is used to see whether there was an effect of stock market on each company. Analysis of Fraud on companies of KRAS, GIAA, WSKT, LPCK, LPKR, and AISA were done by using Dummy in which zero as stock price before the case of Fraud and one as stock price after the case of Fraud. Analysis of bad financial performance on companies of SMCB, PTPP, BBTN, IMPC, CTRA, and BNGA were done by using Dummy in which zero as stock price before bad financial performance and one as stock price after bad financial performance. Data of stock price and IHSG were transformed into Log form. The equity of regression was as follow:

$$
\operatorname{Ln} Y_{\mathrm{it}}: \alpha+\beta_{\text {LnIHSG }}+\beta_{D}+e
$$

Where:

$\operatorname{Ln} Y_{i t}:$ Ln share prices of share i period $\mathrm{t}$

$\beta_{R m}$ : coefficient beta of Ln IHSG of share i period $\mathrm{t}$

$\beta_{D}$ : coefficient beta of Dummy Fraud/financial performance

$\alpha$ : Intercept

e: error. 


\section{Results}

\subsection{Google Search Volume Index}

Descriptive analysis was done by seeing GSVI (Google Search Volume Index) on each SOE company and Non-SOE which was detected Fraud and bad financial performance. Y axis showed the level of popularity. X axis showed search period. Search period for Fraud used weekly Search Volume Index data, while bad financial performance used daily Search Volume Index data.

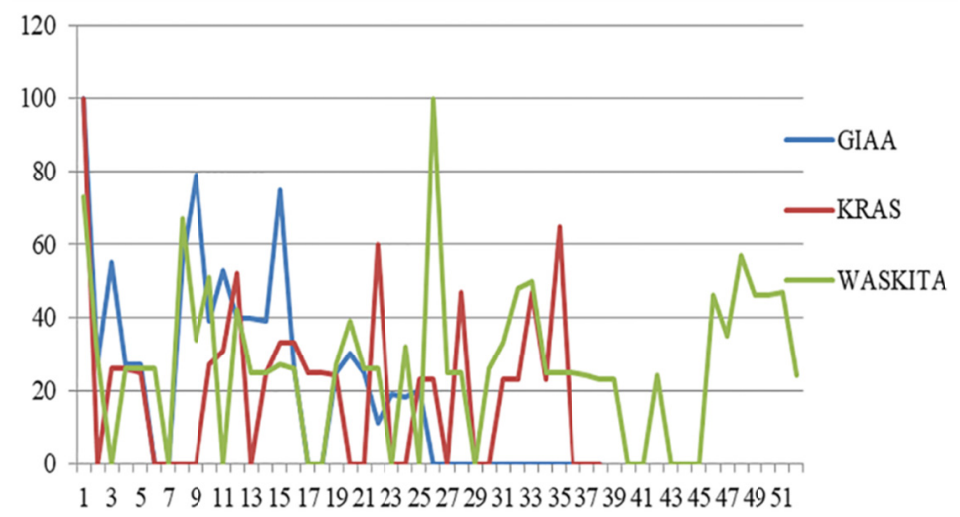

Figure 1. GSVI graph for fraud in SOE

Figures 1 and 2 showed that Fraud in SOE were searched more often by the public rather than Non-BUMN company. It was shown by number of searching points of SOE which were greater than Non-SOE. In addition, Fraud in SOE company were more sought rather than Non-SOE. Fraud in SOE were sought until $51^{\text {st }}$ week after the case, while in Non-SOE were only until $37^{\text {th }}$ week after the case.

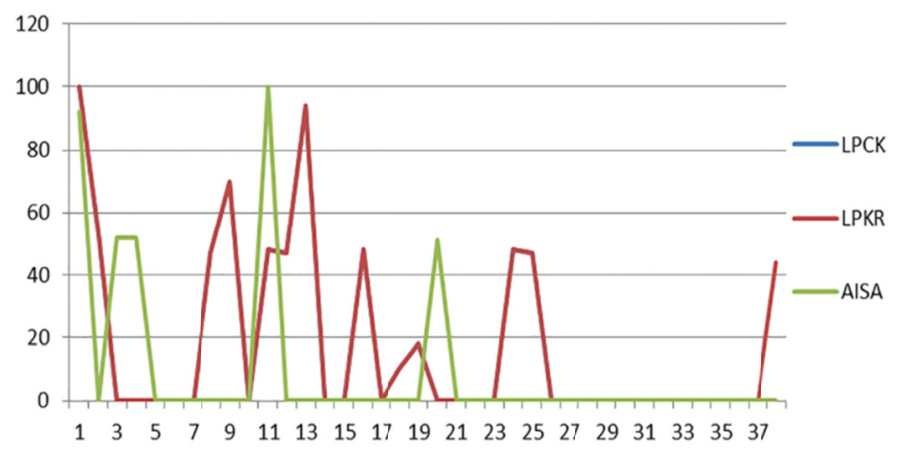

Figures 2. GSVI graph for fraud in Non-SOE

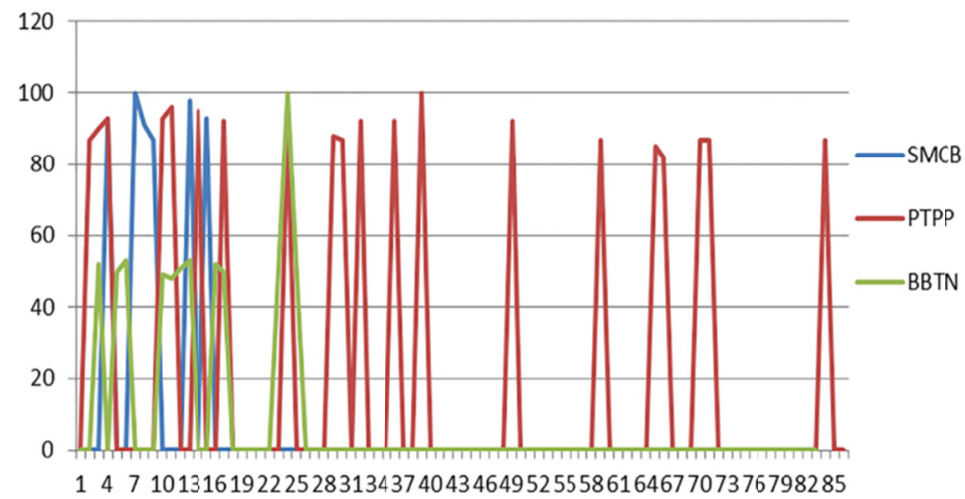

Figure 3. Graph of GSVI for bad financial performance in SOE 
Figure 2 and Figure 4 showed that the bad financial performance in SOE company were more sought by the public than Non-SOE company. It is shown by number of searching points of SOE that is much greater than Non-SOE. Moreover, the bad financial performance in SOE company is searched more frequently than Non-SOE. The bad financial performance in SOE is searched until the $85^{\text {th }}$ day after the case, while in Non-SOE it is only until $33^{\text {rd }}$ day after the case.

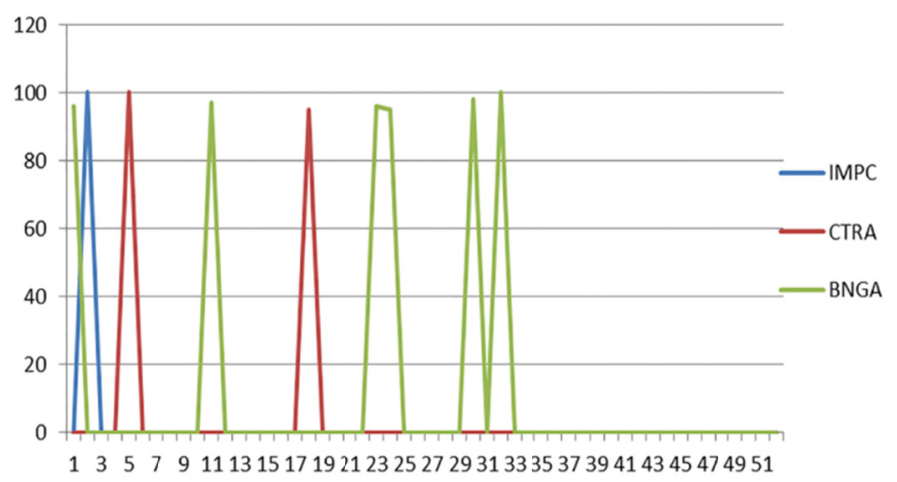

Figure 4. Graph of GSVI for bad financial performance in SOE

\subsection{Classical Assumption Test}

Result of Normality test showed that data spreads out normally with p-value above. Multicollinearity shown by value of Tolerance above 0.1 and it was not occured. There was an indication of Autocorrelation on each sample of company and heteroscedasticity indication. Therefore, analysis of linear regression was done by Newey-West robust standard error.

\subsection{Paired Sample T-Test Difference test}

Difference test by Paired Sample T-test is done on each sample of company to see the effect of negative information on seven day before and seven day after the case.

Table 1. Difference test of paired sample t-test

\begin{tabular}{llllll}
\hline No & Company & $\mathrm{t}$ & $\overline{\mathrm{x}}$ Before(Rp) & $\overline{\mathrm{x}}$ After(Rp) & $p$-value \\
\hline 1 & KRAS & 4.951 & 480.00 & 463.14 & $0.003^{* *}$ \\
2 & GIAA & 2.573 & 499.28 & 464.57 & $0.042^{*}$ \\
3 & WSKT & 5.364 & 1831.42 & 1735.71 & $0.002^{* *}$ \\
4 & LPCK & 41.662 & 1663.30 & 1263.44 & $0.000^{* *}$ \\
5 & LPKR & 7.625 & 246.23 & 223.55 & $0.000^{* *}$ \\
6 & AISA & 8.634 & 1527.85 & 1140.71 & $0.000^{* *}$ \\
7 & SMCB & 4.129 & 2064.28 & 1890.71 & $0.001^{* *}$ \\
8 & PTPP & 4.043 & 2264.28 & 2140.00 & $0.007^{* *}$ \\
9 & BBTN & 4.062 & 2562.85 & 2470.00 & $0.007^{* *}$ \\
10 & IMPC & 16.282 & 905.71 & 867.14 & $0.000^{* *}$ \\
11 & CTRA & 2.858 & 1168.57 & 1127.85 & $0.029^{*}$ \\
12 & BNGA & 2.894 & 1174.28 & 1127.14 & $0.028^{*}$ \\
\hline
\end{tabular}

Notes. *affect significantly $\alpha: 0.05$;

**affect significantly $\alpha: 0.01$.

Table 1 showed p-value for KRAS, GIAA, WSKT, LPCK, LPKR, AISA, SMCB, PTPP, BBTN, IMPC, CTRA, and BNGA were 0.003, 0.042, 0.002, 0.000, 0.000, 0.000, 0.006, 0.000, 0.007, 0.000, 0.029, and 0.028. It showed that there was a difference of stock price on seven days before and seven days after the case of Fraud. p-value for companies of SMCB, PTPP, BBTN, IMPC, CTRA, and BNGA also showed value under 0.05. It showed that there was a difference of stock price on seven days before and seven days after the release of financial report of 2018. Result of Difference Test showed that there was a difference of average of stock price between seven days before and seven days after Fraud and release of financial report of 2018, thus linear 
regression analysis could be done for all samples.

\subsection{Linear Regression Analysis}

Linear regression analysis was used to analyze stock price of one month before and one month after the case. Analysis of linear regression was done on each of company sample. Response of SOE company and Non-SOE for Fraud was compared by seeing the difference of coefficient of Fraud on each sample for Fraud. Response of SOE company and Non-SOE for bad financial performance was compared by seeing the difference of coefficient of bad financial performance on each sample for bad financial performance.

Table 2. Linear regression analysis

\begin{tabular}{llllll}
\hline Company & Coef IHSG & Coef Fraud & Company & Coef IHSG & Coef performance \\
\hline KRAS & $0.837935^{* *}$ & $-0.025333^{* *}$ & SMCB & $1.981744^{*}$ & $-0.03572 * *$ \\
GIAA & $1.211838^{* *}$ & -0.024858 & PTPP & $3.495032 * *$ & $0.035231 * *$ \\
WSKT & $4.375679 * *$ & -0.013727 & BBTN & $2.258552^{* *}$ & $0.014436^{* *}$ \\
LPCK & $2.347901 * *$ & $-0.090361 * *$ & IMPC & 0.480680 & $-0.019837 * *$ \\
LPKR & $1.208512^{* *}$ & $-0.065584^{* *}$ & CTRA & $-1.07550^{* *}$ & $-0.009015^{* *}$ \\
AISA & -1.456151 & $-0.135181^{* *}$ & BNGA & $-0.60506^{* *}$ & $-0.022742^{* *}$ \\
\hline
\end{tabular}

Notes. *affect significantly $\alpha: 0.05$;

**affect significantly $\alpha: 0.01$.

Table 2 showed coefficient of IHSG, Fraud, and bad financial performance. Linear regression analysis showed that Fraud affected significantly in KRAS, LPCK, LPKR, and AISA. Linear regression analysis for Fraud on WSKT and GIAA showed that there were no significant effect of Fraud. It also showed that bad financial performance affected significantly in all SOE and Non-SOE companies. IHSG affected stock price of all sample companies except AISA and IMPC.

\section{Discussion}

Table 2 showed coefficients of IHSG, Fraud, and bad financial performance. Coefficients of Fraud in KRAS, GIAA, WSKT, LPCK, LPKR, and AISA were $-0.025333,-0.024858,-0.013727,-0.090361,-0.065584$, and -0.135181 respectively. Coefficients of IHSG on KRAS, GIAA, LPCK, LPKR, and AISA were -0.025333 , $-0.024858,-0.013727,-0.090361,-0.065584$, and -0.135181 respectively. Linear regression showed that Fraud affected significantly on KRAS, LPCK, LPKR, and AISA. Linear regression analysis for Fraud on WSKT and GIAA showed that there were no significant effect of Fraud. It showed that stock price decrease of SOE company were lower than Non-SOE in response to Fraud. Furthermore, it was also seen that IHSG affected significantly on KRAS, GIAA, WSKT, LPCK, and LPKR. There was an effect of IHSG on SOE company and Non-SOE. It showed that Fraud on SOE company and Non-SOE simultaneously were affected by IHSG, but stock price decrease of SOE company in response to Fraud were still lower than stock price decrease of Non-SOE.

Stock price decrease of SOE, which was lower in response to Fraud were not in line with analysis of GSVI for Fraud on SOE. In which, the amount of searching and duration of searching Fraud on SOE were higher than Non-SOE (Figure 1) (Figure 2). It is not in line with Takeda \& Wakao (2014) and Adachi et al., (2017) who stated that number of searching points on GSVI affected positively stock price decrease. It can be caused by domination of government ownership on SOE company. Soejono (2010) stated that ownership of government's stock affected positively to the stock performance. Ding \& Suardi (2019) also stated that ownership of government's stock on a company will increase the interest of investor to buy. Ownership of stock for a Non-SOE company tend to be owned by private institution and also dominated by public. Public ownership stock on LPCK, LPKR, and AISA were $22.16 \%, 45.76 \%$, and $61.45 \%$ respectively, while for companies of GIAA, KRAS, and WSKT, respectively public ownership were only $13.65 \%, 20 \%$, and $33.96 \%$, and the rest were dominated by government (BEI, 2019)

Coefficient values of bad financial performance on SMCB, PTPP, BBTN, IMPC, CTRA, and BNGA were respectively $-0.03572,0.035231,0.014436,-0.019837,-0.009015,-0.022742$. Coefficient values of IHSG on SMCB, PTPP, BBTN, IMPC, CTRA, and BNGA were respectively 1.981744, 3.495032, 2.258552, 0.480680, -1.07550 and -0.60506 . Response of SOE and Non-SOE for bad financial performance were compared by seeing the coefficient difference of each sample with the same sector. SMCB was compared to IMPC which were in 
basic industry sector; PTPP was compared to CTRA in property sector, while BBTN was compared to BNGA in financial sector. It was seen that in basic industry sector, stock price decrease of SMCB was higher than IMPC. However, in property and financial sectors PTPP and BBTN did not showed stock price decrease in one month after the case, in which CTRA and BNGA showed significant stock price decrease in one month after the case. It showed that stock price decrease of SOE company were lower than Non-SOE in property and financial sectors. In contrast, stock price decrease of Non-SOE company were lower than SOE company in basic industry sector.

Furthermore, it were also seen that IHSG affected significantly on SMCB, PTPP, BBTN, CTRA, and BNGA. There were an effect of IHSG on SOE and Non-SOE companies. It showed that bad financial performance on SOE and Non-SOE were affected by IHSG, while stock price decrease of SOE company in response to bad financial performance were still lower than stock price decreases of Non-SOE in property and financial sectors. Stock price decrease of SOE which were lower in response to bad financial performance were not in line with analysis of GSVI for bad financial performance in SOE, in which the amount and duration of searching bad financial performance on SOE company were higher than Non-SOE company. Similar to response on Fraud, stock price decrease of SOE that were lower in response to bad financial performance in property and financial sector were affected by domination of ownership of government's stock on SOE company in property and financial sectors.

Government stock ownership on PTPP and BBTN were 51\% and 60\% (BEI, 2019). SOE response to bad financial performance, which were better than Non-SOE in property and financial sectors, were also affected by participation of government in minimizing risk of failure which is in SOE company. According to Zhang et al., (2018), government ownership affected a decrease of company's risk. It occured by government participation in investment activity of SOE company, thus it could cut down the failure in SOE company. SOE company in basic industry sector namely SMCB showed a stock price decrease which was higher than Non-SOE company namely IMPC in response to bad financial performance. It was also affected by ownership of stock of SMCB, which was not dominated by government (BEI, 2019). It was seen that coefficient of bad financial performance in PTPP and BBTN has positive value which showed that stock price of PTPP and BBTN after the case of bad financial performance is higher than before the case.

It occurred by the influenced of Conservatism Bias and Overconfidence Bias. According to Wu et al., (2016) Conservatism Biases pushed investor to invest on a company which was trusted by investor, thus investor tend to ignore newest information about that company. According to Qasim et al., (2019) Overconfidence Bias would affect decision making to invest, where investor felt too confidence to select company. In this study it was supposed that investor had a conservative perception and confidence that SOE company would safer even there were negative information in SOE company. Therefore, stock price of PTPP BBTN as SOE in response bad financial performance tends to be better than Non-SOE company.

Result of study also showed that Fraud had stronger effect than bad financial performance in SOE and Non-SOE companies. It could be affected by GSVI value for SOE and Non-SOE companies in response to Fraud and bad financial performance. Fraud were searched more frequently by public rather than bad financial performance. It was shown by number of searching points for Fraud in SOE and Non-SOE companies, which were greater than bad financial performance. In addition, there was also a perception of investor on Fraud that was worse than bad financial performance. The investor considers that bad financial performance could still be fixed by improving company financial performance.

\section{Acknowledgements}

Thank to Bogor agricultural university as the institution that gives a chance to write research paper. Author gives thank to the research supervisor, Dr Tony Irawan, SE, M.app.Ec \& Dr Ir Trias Andati, MM, Msc, who provided insight and expertise that greatly assisted the research. Author would like to thank relatives from Bogor Agricultural University, who always supported author to finish this paper.

\section{References}

Ang, J. S., \& Ding, D. K. (2006). Government ownership and the performance of government-linked companies: the case of Singapore. Journal of Multinational Financial Management, 16(1), 64-88. https://doi.org/10.1016/j.mulfin.2005.04.010

Beers, B. (2019). Why do stock price changes based on news reports? Retrieved from http://www.investopedia.com

Cox, R. A. K., \& Weirich, T. R. (2002). The stock market reaction to fraudulent financial reporting. Managerial Auditing Journal, 17(7), 374-382. https://doi.org/10.1108/02686900210437471 
Cuellar, B., Gadea, J. A., \& Callen, Y. (2009). Stock price reaction to non-financial news in european technology companies. European Accounting Review, 20(1), 81-111. https://doi.org/10.1080/09638180903384650

Ding, M., \& Suardi, S. (2019). Government Ownership and Stock Liquidity: Evidence from China. Emerging Market Review, 40, 1-54. https://doi.org/10.1016/j.ememar.2019.100625

Feroz, E. H., Park, K., \& Pastena, V. S. (1991). The financial and market effects of the SEC's accounting and auditing enforcement releases. Journal of Accounting Research, 29, 107-142. https://doi.org/10.2307/2491006

Google Search Volume Index. (2019). Google Trend. Retrieved from https://trends.google.com/trends/

Indonesia Stock Exchange. (2019). Profil Perusahaan Tercatat. Retrieved from http://www.idx.co.id

Qasim, M., Hussain, R. Y., Arshad, M. G., \& Mehboob, I. (2019). Impact of Herding Behavior and Overconfidence Bias on investors' decision-making in Pakistan. Accounting, 5, 81-90. https://doi.org/10.5267/j.ac.2018.7.001

Rao, S. (1997). The effect of announcement of Bribery, Scandal, White Collar Crime, and Illegal Payment on returns to shareholders. Journal of Financial and Strategic Decisions, 10(3), 55-62.

Razak, N. H., Ahmad, R., \& Joher, H. A. (2011). Does Government Linked Companies (GLCs) perform better than non-GLCs? Evidence from Malaysian listed companies. Journal of Applied Finance \& Banking, 1(1), 213-240. Retrieved from http://www.scienpress.com/Upload/JAFB\%2fVol\%201_1_10.pdf

Rui, X. (2015). Google Search Volume Index: Predicting returns, Volatility and trading volume of tech stocks. (Master Thesis, Duke University, Durham, United States). Retrieved from https://sites.duke.edu/djepapers/files/2016/10/xurui-dje.original.pdf

Soejono, F. (2010). Ownership type and company performance: Empirical studies in the Indonesian Stock Exchange. Journal of Indonesian Economy and Business, 25(3), 338-352. https://doi.org/10.22146/jieb.6288

Takeda, F., \& Wakao, T. (2014). Google search intensity and its relationship with returns and trading volume of Japanese stocks. Pacific-Basin Finance Journal, 27, 1-18. https://doi.org/10.1016/j.pacfin.2014.01.003

Tay, L., Puah, C. H., Brahmana, R. K., \& Malek, N. I. (2016). The effect of white collar crime announcement on stock price performance. Journal of Financial Crime, 23(4), 1126-1139. https://doi.org/10.1108/JFC-03-2015-0016

Widayanti, R., Ekawati, H., Dorkas, A., Rita, M. R., \& Sucahyo, U. S. (2009). Manajemen Keuangan. Salatiga, ID: Fakultas Ekonomi UKSW.

Wu, C. H., Wu, C. S., \& Liu, V. W. (2009). The Conservatism Bias in an emerging stock market: Evidence from Taiwan. Pacific-Basin Finance Journal, 17(4), 494-505. https://doi.org/10.1016/j.pacfin.2008.12.002

Yahoofinance. (2019). Historical Data. Retrieved from http://www.yahoofinance.com

Zhang, C., Rasiah, R., \& Cheong, K. (2018). Board independence, State ownership and stock return volatility during Chinese state enterprise reform. Journal of Business in Society, 18(2), 220-232. https://doi.org/10.1108/CG-08-2016-0172

\section{Copyrights}

Copyright for this article is retained by the author(s), with first publication rights granted to the journal.

This is an open-access article distributed under the terms and conditions of the Creative Commons Attribution license (http://creativecommons.org/licenses/by/4.0/). 